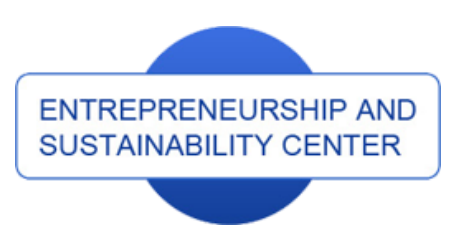

Publisher

http://jssidoi.org/esc/home enterprise

europe

network

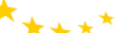

Business Support on Your Doorstep

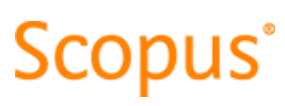

\title{
APPROACH TOWARDS FEMALE AFRICAN MIGRANT ENTREPRENEURSHIP RESEARCH
}

\author{
Jane Njaramba ${ }^{1}$, Hilary Whitehouse ${ }^{2}$, Darren Lee-Ross ${ }^{3}$ \\ 1,2,3 James Cook University, College of Arts, Society and Education, P.O Box 6811, Cairns QLD 4870, Australia \\ E-mails: E-mails: ${ }^{1}$ jane.njaramba@my.jcu.edu.au; ${ }^{2}$ hilary.whitehouse@jcu.edu.au; ${ }^{3}$ Darren Lee-Ross@jcu.edu.au
}

Received 10 February 2018; accepted 10 May 2018; published 30 June 2018

\begin{abstract}
This paper sets out my rationale and objective, the motivating factors, methodology, types of data collection and analysis. The purpose of the research is to investigate and analyse the entrepreneurial experiences of Migrant African Women Entrepreneurs (MAWEs) in Regional Queensland whose businesses depend on tourism. This study is inspired by my personal experience as a migrant African woman and informed by my doctoral study in progress. Having migrated from Africa to Australia seven years ago, I noted numerous aspiring entrepreneurs among migrant African women and developed an interest in learning more about the experiences of this group, and a concern regarding the extent of their needs. The objectives are to explore MAWEs' motivation, identify the factors that enable them, the barriers they encounter and the challenges they face. This will involve excavating the role of formal and informal learning practices. Tenets of feminist theory are used to examine opportunities for formal adult education, peer-to-peer learning, and work experience that facilitates the establishment and sustainability of small business. As an insider, I can provide insights and give the participants a voice by articulating their observation and encouraging the growth of small business which contributes to the economy of regional Australia.
\end{abstract}

Keywords: women; entrepreneurship; standpoint theory

Reference to this paper should be made as follows: Njaramba, J.; Whitehouse, H.; Lee-Ross, D. 2018. Approach towards female African migrant entrepreneurship research, Entrepreneurship and Sustainability Issues 5(4): 1043-1053. http://doi.org/10.9770/jesi.2018.5.4(24)

JEL Classifications: O10, O15

\section{Introduction}

The current Australian Government's policy has been promoting small business entrepreneurship and innovation (Australia Government, 2015). The Global Entrepreneurship Monitor (GEM) survey reports that Australia is an innovation-driven economy (Kelly et al., 2011). My research concentrates on migrant women who are included in the government's commitment to providing ongoing support for mentoring, education and training. The involvement in my family's business, in both Africa and Australia, has enabled me to experience the complexities 
of starting and operating a small business. I observed the demands and differences from two contrasting cultural positions. The topic suggests that the most appropriate form of feminist analysis for this research is Standpoint theory and the study focuses on an area of migrant experience that is not adequately researched.

Research question. What is the most appropriate form of feminist analysis for research into African migrant women entrepreneurship?

\section{Review of literature}

\section{Migrant women entrepreneurship}

According to the Organization for Economic Cooperation and Development (OECD, 2013), research in entrepreneurship is a growing area in educational and social research. There is increasing recognition of the relevance and importance of entrepreneurship for migrant women from developing countries who have settled in developed economies and aspire to become successful business owners (Poggesi et al., 2015). Nevertheless, there is limited literature on the subject. Most migrant entrepreneurs are male, yet their business dynamics often depend on the unpaid and unacknowledged support of their wives and family members (Collins \& Low, 2010). Bird and Brush, (2002) argue that feminine skills are often ignored or excluded in the entrepreneurship literature. Although this varies from country to country (Collins, 2003), it is a significant issue in Australia because, increasingly, women are becoming entrepreneurs in their own right. A body of literature on women entrepreneurs retains the notion that the entrepreneur or entrepreneurship exists independently of the person doing it (Galloway, Kapasi, \& Sang, 2015). Ogbor (2000) argues that the general concept of entrepreneurship emerges as fundamentally more masculine than feminine, and more heroic than cowardly. In this context, males are seen as the archetype of entrepreneurs whereas females, at best, are confined to what Bowen and Hisrich (1986) term as 'entrepreneurial ghettos' (p. 394). Ogbor asserts that traditionally, female participation is the antithesis of entrepreneurial norms because of the following gender inequalities: male dominance versus female submissiveness, male independence versus female dependence, and male achievement versus female subjugation.

\section{Barriers and challenges}

According to Collins and Low (2010), to survive economically, migrant women often start their own small businesses because they are unable to access the mainstream labour market. In the authors, personal experience, typical examples of retail businesses include the selling and braiding of hair, dressmaking, artefacts, and supply of African foods and clothes.

Reluctance or inability to branch out to more diverse enterprises may be due to a different regulatory environment, restrictive government regulations, institutional orientations, and lack of proper networks. Other factors include lack of familiarity with the Australian business environment, taxation and legal requirements, lack of capital, exposure to different social networks, and lack of local knowledge, culture and language (Collins, 2008).

Self-employment promotes self-sufficiency and is a means to rise above poverty and marginalisation. The contribution of migrant entrepreneurs to the Australian economy is an area where comparative international knowledge is evolving but underdeveloped (OECD, 2010) while, Collins and Low (2010) study contend that migrant women from developing countries who settle and start their ventures in developed economies are not well studied. 


\section{Informal adult education}

Adult learning (peer-to-peer) is a personal process shaped by the context of adult life and the society in which one lives (Merriam et al., 2012). Entrepreneurial learning focuses on the knowledge, skills, abilities, and attitudes of actual or potential entrepreneurs (Erikson, 2003). Knowledge acquired through adult learning is centred on the cognitive processes related to acquiring, storing, and making meaning of new information (Merriam et al., 2012). Schugurensky (2000) proposes three forms of learning: self-directed which is intentional and conscious, incidental, and social, or tacit. Types of informal learning differ among themselves in terms of intentionality and awareness at the time of learning (Merriam et al., (2012). This study will specifically research informal learning that embraces activities such as learning from other businesswomen, family, friends and co-workers, on-the-job learning, engaging in business mentoring, and learning through trial and error (Dawe \& Nguyen, 2007). Informal learning provides migrants with foundation skills to integrate into their new communities, upon which further learning can be built. Small business owners learn through doing, and much of their learning is focused on current or real issues contextually embedded in their environment (Dawe \&Nguyen, 2007).

\section{Research methodology}

Case study methodology and feminist theory sit well together because both focus on illuminating participants' lived experiences. Qualitative research is best suited to obtaining a rich description of a phenomenon from the viewpoint of the people who experience it (Oakley, 1998 \& Creswell, 2014). Yin (2014) describes a case study as "an empirical inquiry that investigates a contemporary phenomenon in depth and within its real-world context" (p. 16). According to Creswell (2014), case studies "are a qualitative design in which the researcher explores in depth a program, event, activity, and process, or one or more individuals" (p. 241). Qualitative methods are appropriate for feminist research to reveal and understand subjective experiences of women in contemporary society (Depner, 1981). Respect for the experience and perspective of the other is upheld, with feminist researchers expressing commitment to "realising as fully as possible women's voices in data gathering and preparing an account that transmits those voices" (Olesen, 1994 p. 167).

According to Creswell (2014), the researcher will be the primary data collection instrument, and this necessitates identifying personal values, assumptions, and biases at the outset of the study. The researcher's worldview is a collection of beliefs, a definition of self, and relationships that occur within the world. These beliefs influence and inform the design and conduct of a research project (Creswell, 2014). Clear justification of methodology and methods, together with the explanation of the underlying theoretical perspectives and epistemology, ensures a strong research design and ultimate convincing outcomes of research (Crotty, 1998). A case study methodology will be employed to gain a deep understanding of participating women. Based on my reading of Yin (2014) and Creswell (2014), this is best achieved using MAWEs as informants in an interview situation (Patton, 2002).

This research draws upon a qualitative study in progress, which aims to understand small business entrepreneurship among migrant African women in North Queensland, a feminist study of lived experience, motivation and learning. In this study, there is a need for migrant women to have entrepreneurial skills and abilities to enable them to deal with life's challenges and an uncertain future. Henry et al. (2005) argue for the need for education because entrepreneurs will benefit from learning an innovative approach to problem-solving, adapting to change, becoming more self-reliant and developing their creativity.

\section{Feminist approach}

Data collection methods will include transcripts interviews, surveys and documents. All the data collected from the documents, surveys and transcripts will form the text for analysis. 
Given (2016) argues that a feminist lens may be used where thematic analysis and coding process contribute to feminist theory. Viewing entrepreneurship through a feminist lens opens up avenues for innovative methodological approaches beyond the conventional methods employed in the majority of research (Galloway et al., 2015). The ultimate aim of the feminist research is to 'capture women's lived experiences in a respectful manner that legitimises women's voices as a source of knowledge' (Campbell \& Wasco, 2000, p.787). Feminist research has from its early stages been engrossed with the politics of knowing and being known according to Lather (1992). The researcher is motivated by, and concerned with, promoting social justice for women and brings feminist knowledge to the research process (Morris, 2016). Feminist research focus is sharply on gender domination and discrimination within patriarchal societies (Polit \& Beck, 2014).

Ahl and Marlow (2012) have advocated a feminist approach to interpret entrepreneurship. Ahl (2006) argues there is a need to use a feminist perspective to examine the gendering of entrepreneurship and entrepreneurs, rather than merely regarding gender as a variable in quantitative investigations. Feminist social research has often been equated with a woman-to-woman, sensitive style of qualitative interview, observation or life history, or one that involves research participants in the production of knowledge (Ramazanoglu \& Holland, 2002). Ramazanoglu and Holland, (2002) argue that feminist knowledge of gender should include practical social investigation of gendered lives, experiences, relationships and inequalities.

Harding's (1987) position demands that we should learn to look more closely at what makes the most influential feminist research so powerful. She suggests studying women from the perspective of their own experiences so that they/we can better understand our situations in the world. Research should be designed for women instead of simply about women. The feminist perspective enables the researcher to probe issues of the power relations between the researcher and researched, objectivity versus subjectivity, and found versus constructed worlds (Lather, 1992). Feminist research values and prioritises the voices and experiences of women (Beckman, 2014).

In fostering understanding of women's experiences, feminist perspectives also 'carry messages of empowerment that challenge the encircling of knowledge claims by those who occupy privileged positions' (Hesse-Biber, 2012, p 3). As a feminist researcher, I assert that migrant women's voices have been traditionally silenced or distorted. As stated by Gray (2014), my aim, as the researcher is to understand the experiences of MAWEs, my own experience, and my influence on the research. Feminist research is actively engaged in challenging inequalities or injustices and improving women's lives (Gray, 2014).

As Holland \& Ramazanoglu, (2002) note, feminist knowledge of women's lives cannot be assumed or generalised without qualification and empirical investigation. Haraway (1991) explains that to move towards feminist objectivity, knowledge has to be situated.

According to Hjorth et al. (2004) study, feminist perspective is thus necessary for studies on entrepreneurship to avoid taking a prevalent masculine norm for granted and to be able to make women entrepreneurs visible. Feminist research is not just on women, but for women and, with women (Fonow \& Cook, 1991). Harding (1991) also states that by using feminist theories as a conceptual lens, a more inclusive social research practice can be created.

The data gathered will be analysed using a conceptual/theoretical framework of thematic analysis (Braun \& Clarke, 2013) and Feminist standpoint theory (FST) - Dorothy Smith and Sandra Harding (2004) are the pioneers. Feminist epistemologies include feminist empiricism, feminist standpoint, and feminist postmodernism (Harding 1991). Feminist standpoint theory claims that the only way of knowing a socially constructed world is to know it from within (Smith, 1997). The very notion of standpoint would be the act of interpretation; one that puts 
the positioning of "outsider-within" to work (Collins, 2004). I will be drawing on Haraway's suggestion of a gift of vision; of the situation as a visual tool.

\section{Feminist Standpoint analysis}

This study draws on standpoint theory (Harding, 1991) and situated feminist knowledge (Haraway, 1988). Bhavnani (1993) proposed set criteria against which any social scientific inquiry can be evaluated for its claim to be feminist (as cited in Handforth \& Taylor, 2016). Ahl et al.,'s study (2006), was based on feminist analysis of women's entrepreneurship, and Brettell (2007) researched immigrant women in small business following their biographies of becoming entrepreneurs. Feminist scholars working within some disciplines such as Dorothy Smith, Nancy Hartsock, Sandra Harding, Patricia Hill Collins, and Donna Haraway have advocated researching women's lived experiences.

Feminist standpoint theory is useful in understanding some of the facets of marginalisation that migrant African Australian women entrepreneurs face. In accordance with the views of Harding (2004), I will seek to do the work of excavating, shifting the focus from the theoretical concerns in the debates on the tensions between feminism, and marginalised African migrant entrepreneurs to the voices of the women rendered vulnerable by these debates. Standpoint theory is based on the assumption that those experiencing intersecting inequalities have adequate knowledge about it and thus should be the subjects of inquiry (Carastathis, 2014). Growth in women migrant entrepreneurship in Australia suggests a need for policies to be sensitive to matters related to the intersection of ethnicity and gender (Collins, 2008). Davis (2008) defines intersectionality as the "interaction between gender, race, and other categories of difference in individual lives, social practices, institutional arrangements, and cultural ideologies and the outcomes of these interactions in terms of power" (p.68). The author's choice to include intersectionality in this study is an appropriate framework for analysing the experiences of women because the complexity of their experiences will be examined from gender, class, and race perspective.

A feminist standpoint, achieved through struggle both against male oppression and toward seeing the world through women's eyes, provides the possibility of more complete and less distorted understandings (Lather, 1992). I will adapt Hennessy (1992) idea that, the application of feminist standpoint will help shape structures of power, work and wealth when it is conceptualised into reality from the vantage point of MAWE's lives. Feminist thinking and practice require taking steps from the 'margins to the centre' while eliminating boundaries that privilege dominant forms of knowledge building, boundaries that mark who can be a knower and what can be known' (Hesse-Biber, 2012, p 3).

Hartsock (1992) defines standpoint feminism as the attempt to develop the methodological base provided by Marxian theory; an important epistemological tool for understanding and opposing all forms of domination. Standpoint theorist Sandra Harding (1993) argues that science is socially constructed. Hennessey (1992) affirms that feminist standpoint theory empowers women's ways of knowing. According to Hesse-Biber (2012), standpoint theories, feminist empiricism, postmodernism, and transnational perspectives all recognise the importance of women's lived experiences in the quest of excavating subjugated knowledge. Dorothy Smith (1987) stresses the necessity of starting research from a woman's perspective. Smith also claims that women's accounts of "daily/nightly" experience, as its ground for knowledge (Dorothy Smith, 1997, p. 394).

\section{Structuralism and poststructuralism}

Poststructuralist feminists have questioned the authority of the data documented by feminist standpoint theory. By looking at the difference between standpoint and poststructuralist perspectives, the researcher gains a more complex and theoretically richer set of explanations of the lives of the oppressors and the oppressed (Hesse-Biber, 
2012). Gough and Whitehouse, (2003) argue that the "feminist poststructuralist approach can be very informative and revealing of certain dimensionalities that may otherwise be ignored or silenced within the field" (p.9). Poststructuralist theorists critique Standpoint theory as, "the knowledge project which assumes that correctly produced knowledge will lead to the adoption of the best political strategies"(Andermahr et al., 1997).

In my reading of feminist standpoint theorists and poststructuralist feminists, a consistent difference is that the former are studying knowledge that is not legitimated by masculine domination whereas poststructuralist feminists are explicitly studying the discursive formations that shape social relations and knowledge. However, I would argue that both groups of theorists are studying structures of power in general, and both have a political goal, precisely the liberation of women in an egalitarian society. Generally, both groups have a similar object of study - power and knowledge, but the approach of poststructuralist researchers concentrates on the language and meanings that underlie the "ontological and epistemological understandings" (as Cited in Gough \& Whitehouse, 2003).

\section{Study Locations}

Knight (1921), and Basu and Altinay, (2002) claim that the motives that drive people towards business entry and self-employment are profit, desire to take a risk, and a spirit of adventure but the assumption that all the businesses established by MAWEs are driven by growth and profit maximisation objectives is questionable (LeeRoss \& Ashley, 2009). These aspects will be investigated in the research. Tourism and leisure industries are primarily located in attractive regions, where there is a much higher concentration of lifestyle entrepreneurs, and this is often the primary motivation for entrepreneurial activity (Peters et al., 2009). The project study areas, Cairns and Townsville, are hubs for tourism and are popular travel destinations for foreign and local tourists because of their tropical climate.

\section{Multiple sources of data collection}

Oakey (1998) argues that methodology has been gendered, but it is possible to conduct feminist qualitative research using a range of research methods. The study employs the Gray (2014) methodology that is grounded in the interpretivist-constructivist paradigm, which offers a flexible research design that requires placing the person experiencing the phenomenon central to the study. Reinharz and Davidman 1992 argue that feminist researchers should be careful to differentiate their own experience from the experience of other women while valuing their personal experience. Olesen (1994) states that respect for the experience and viewpoint of the other women is maintained, with feminist researchers totally committed to realising women's voices in data gathering entirely and conveying those voices. Reinharz (1983) too argues for positioning feminist research within qualitative traditions of social inquiry. The feminist methodology is shaped by feminist theory, politics, and ethics, and grounded in women's experience (Ramazanoglu \& Holland, 2002).

Oakley (1998) states that qualitative methods are considered non-scientific and associated with interpretivism, subjectivity and femininity, but the use of multiple sources of data collection is a significant strength of the case study approach (Burns, 2000). Multiple sources allow for triangulation through converging lines of inquiry. Corroboration makes a case study report more convincing (Burns, 2000). Different data collection methods will be utilised in this study and will use document study, site visits, group and individual interviews, which will include a survey questionnaire in order to strengthen the validity and reliability of the findings. Document study will include official and public documents, organisational documents, newspaper articles, and government reports. These will be sourced to give the researcher a broad understanding of the migrant entrepreneurial context. The site visits will be conducted to observe the nature of the business, the environment, customer interactions, 
The International Journal

ENTREPRENEURSHIP AND SUSTAINABILITY ISSUES

ISSN 2345-0282 (online) http://jssidoi.org/jesi/

2018 Volume 5 Number 4 (June)

http://doi.org/10.9770/jesi.2018.5.4(24)

employees, and working dynamics of the business. This will allow the researcher to contextualise the participant in her place of business. Combining site visits with in-depth individual interviews would be sensible and practical.

Five focus groups in each city will be conducted, with the aim of bringing the participants together for productive conversation. A semi-structured interview guide will be used for the group interviews to ask the participants questions about their experiences of entrepreneurship in Australia. Small groups of a minimum of four participants will be organised, lasting approximately one hour. Interviews will be recorded and transcribed and may take place at any location that suits the participants. These groups encourage participants to talk to one another. The data generated is valuable, but the informal exchanges that arise during general interactions are equally essential. Wilkinson and Morton (2007) argue that the focus groups are relevant to feminist research because they are a contextual method. They avoid focusing on the individual, devoid of social context, or separate from interactions with others. Secondly, focus groups are a relatively non-hierarchical approach because they shift the balance of power away from the researcher towards the research participants.

In-depth, semi-structured individual interviews will be undertaken with five participants in each city, and these will include professional women in their own private practice or who are seeking to be such. Interviews will be conducted face-to-face and, like the focus groups will be scheduled at the convenience of the participant, at any location that suits them and will last approximately one hour. Interviews will be recorded and transcribed then returned to each interviewee for personal checking. This method will also be applied to interviews with five industry partners. In-depth conversations and group discussions serve as a medium to gain rich detail in the women's stories we seek to explore (Gray, 2014). Face-to-face interviews, mainly from a feminist perspective, allow for a degree of rapport, and can thus elicit meaningful information. Feminist researchers also contend that as women tend to be highly skilled in human interaction and conversation, interviews are well suited to feminist researchers (Reinharz \& Davidman 1992, p. 20). A structured questionnaire will be developed to address demographic details at the same time as the interviews with open and closed questions set.

\section{Conclusions}

This research involves a topical study involving migrant African women entrepreneurs. The study illustrates guiding principles of a feminist theory, in which women's issues are central. The study objective reflects on how Feminist Standpoint Theory contributes to our understanding of migrant women entrepreneurs in North Queensland and their lived experience. The research focus is directed towards learning from the participants' experiences in all aspects of their lives, understanding their stories and the meaning they attribute to them. This study will generate empirical data on entrepreneurship and contribute to an expanding body of knowledge. It is hoped that the findings will illuminate the experiences and needs of MAWEs and potentially influence future policy.

\section{References}

Ahl, H., Högskolan i, J., Högskolan för lärande och, k., \& Hlk, L. 1. E. (2006). Why research on women entrepreneurs needs new directions. Entrepreneurship Theory and Practice, 30(5), 595-621. https://doi.org/10.1111/j.1540-6520.2006.00138.x

Ahl, H., \& Marlow, S. (2012). Exploring the dynamics of gender, feminism and entrepreneurship: advancing debate to escape a dead end? Organization, 19(5), 543-562. https://doi.org/10.1177/1350508412448695

Australia Government. (2015). Strategic policy initiatives and new developments: Innovation policy. Retrieved from http://www.industry.gov.au/innovation/reportsandstudies/Documents/InnovationPolicyReportOct2015.pdf 
The International Journal

ENTREPRENEURSHIP AND SUSTAINABILITY ISSUES

ISSN 2345-0282 (online) http://jssidoi.org/jesi/

2018 Volume 5 Number 4 (June)

http://doi.org/10.9770/jesi.2018.5.4(24)

Beckman, L. J. (2014). Training in Feminist Research Methodology: Doing Research on the Margins. Women \& Therapy, 37(1-2), 164177. https://doi.org/10.1080/02703149.2014.850347

Bhavnani, K.-K. (1993). Tracing the contours: Feminist research and feminist objectivity. Women's Studies International Forum, 16(2), 95104. https://doi.org/10.1016/0277-5395(93)90001-P

Bowen, D. D., \& Hisrich, R. D. (1986). The female entrepreneur: A career development perspective. Academy of management review, 11(2), 393-407. https://doi.org/10.5465/AMR.1986.4283366

Brettell, C. B. (2007). Immigrant women in small business: Biographies of becoming entrepreneurs. In L. P. Dana (Ed.), Handbook of research on ethnic minority entrepreneruship: A co-evolutionary view on resource management (pp. 83-98). Cheltenham, UK: Edward Elgar.

Basu, A., \& Altinay, E. (2002). The interaction between culture and entrepreneurship in London's immigrant businesses. International Small Business Journal, 20(4), 371-393. https://doi.org/10.1177/0266242602204001

Bird, B., \& Brush, C. (2002). A gendered perspective on organizational creation. Entrepreneurship Theory and Practice, 26(3), 41-66

Braun \& Clarke (2013). Successful qualitative research: A practical guide for beginners. Thousand Oaks, CA: Sage

Burns, R. (2000). Burns, R. B. (2000). Introduction to research methods (Vol. 4th). London: SAGE.

Campbell, R., \& Wasco, S. M. (2000). Feminist approaches to social science: Epistemological and methodological tenets.

https://doi.org/doi.org.elibrary.jcu.edu.au/10.1023/A:1005159716099

Carastathis, A. (2014). The concept of intersectionality in feminist theory. Philosophy Compass, 9(5), 304-314.

https://doi.org/10.1111/phc3.12129

Creswell, J. W. (2014). Research design: qualitative, quantitative, and mixed method approaches (4th ed.). Thousand Oaks, CA: Sage Publications, Inc.

Crotty, M. (1998). The foundations of social science: Meaning and perspective in the research process. London, UK: Sage.

Collins, J. (2003). Cultural diversity and entrepreneurship: Policy responses to immigrant entrepreneurs in Australia. Entrepreneurship \& Regional Development, 15(2), 137-149. https://doi.org/10.1080/0898562032000075168

Collins, J. (2008). Immigrant entrepreneurs in Australia: Regulations and responses. Retrieved from https://opus.lib.uts.edu.au/research/bitstream/handle/10453/10371/2008001344.pdf?sequence=1

Collins, J., \& Low, A. (2010). Asian female immigrant entrepreneurs in small and medium sized businesses in Australia. Entrepreneurship and Regional Development, 22(1), 97-111. https://doi.org/10.1080/08985620903220553

Dawe, S., \& Nguyen, N. (2007). Education and training that meets the needs of small business: A systematic review of research (1921170859). Retrieved from http://files.eric.ed.gov/fulltext/ED499699.pdf

Davis, K. (2008). Intersectionality as buzzword: A sociology of science perspective on what makes a feminist theory successful. Feminist theory, 9(1), 67-85. https://doi.org/10.1177/1464700108086364

Depner, C. (1981). Towards the further development of feminist psychology. Paper presented at the mid-winter conference of the Association for Women in Psychology, Boston

Erikson, T. (2003). Towards a taxonomy of entrepreneurial learning experiences among potential entrepreneurs. Journal of Small Business and Enterprise Development, 10(1), 106-112. https://doi.org/10.1108/14626000310461240

Fonow, M. M., \& Cook, J. A. (1991). Beyond methodology: Feminist scholarship as lived research. Bloomington, IL: Indiana University Press. 
Gough, A., \& Whitehouse, H. (2003). The "Nature" of Environmental Education Research from a feminist poststructuralist Viewpoint. Canadian Journal of Environmental Education.

Galloway, L., Kapasi, I., \& Sang, K. (2015). Entrepreneurship, leadership, and the value of feminist approaches to understanding them. Journal of Small Business Management, 53:(3), 683-692. https://doi.org/10.1111/jsbm.12178

Given, L. M. (2016). 100 questions (and answers) about qualitative research. Thousand Oaks, CA: Sage

Gray, D. E. (2014). Doing research in the real world (Vol. Third). Los Angeles, CA: SAGE.

Handforth, R., \& Taylor, C. A. (2016). Doing academic writing differently: A feminist bricolage. Gender and Education, 28(5), 1-17. https://doi.org/10.1080/09540253.2015.1115470

Haraway, D. (1988). Situated knowledges: The science question in feminism and the privilege of partial perspective. Feminist Studies, 14(3), 575-599. https://doi.org/10.2307/3178066

Haraway, D. J. (1991). Simians, cyborgs, and women: the reinvention of nature. New York: Routledge

Harding, S. (1987). Feminism and methodology. Bloomington: Indiana University press

Harding, S. (1987). Introduction: Is there a feminist method? In S. Harding (Ed.), Feminism and methodology (pp. 1-14). Bloomington, MI: Indiana University Press

Harding, S. (2004). A socially relevant philosophy of Science? Resources from standpoint theory's controversialist. Hypanthia, 19(1), 2547. https://doi.org/10.1111/j.1527-2001.2004.tb01267.x

Harding, S. G. (1991). Whose science? Whose knowledge? Thinking from women's lives. Milton Keynes: Open University Press

Henry, C., Hill, F., \& Leitch, C. (2005). Entrepreneurship education and training: can entrepreneurship be taught? Part II. Education+ Training, 47(3), 158-169. https://doi.org/10.1108/00400910510586524

Hartsock, N. (1992). Political Theory -- Simians, cyborgs, and women: The reinvention of nature by Donna J. Haraway (Vol. 86, pp. 511). Washington: Cambridge University Press.

Hesse-Biber, S. N. (2012). Handbook of feminist research: theory and praxis (Vol. 2nd). Thousand Oaks: SAGE.

Hermessy, Rosemary. (1992) Materialist feminism and the politics of discourse. New York. Routledge.

Kelley, D., Bosma, N. S., \& Amorós, J. E. (2011). Global entrepreneurship monitor 2010 executive report. Retrieved from http://dspace.library.uu.nl/handle/1874/228073

Knight, F.H. (1921). Risk, uncertainty and profit, Chicago, IL: University of Chicago Press

Lee-Ross, D., \& Lashley, C. (2009). Entrepreneurship and small business management in the hospitality industry (Vol. 1). Oxford: Butterworth-Heinemann

Lather, Patti. (1991). Getting smart: Feminist research and pedagogy with/in the postmodern.

New York: Routledge.

Marlow, S., \& McAdam, M. (2012). Analyzing the influence of gender upon high technology venturing within the context of business incubation. Entrepreneurship theory and practice, 36(4), 655-676. https://doi.org/10.1111/j.1540-6520.2010.00431.x

Morris, S. M. (2016). More than Human: Black Feminisms of the Future in Jewelle Gomez'sThe Gilda Stories. The Black Scholar, 46(2), 33-45. https://doi.org/10.1080/00064246.2016.114799

Merriam, S. B., Caffarella, R. S., \& Baumgartner, L. M. (2012). Learning in adulthood: A comprehensive guide. Retrieved from http://site.ebrary.com.elibrary.jcu.edu.au/lib/jcu/detail.action?docID=10546621 
The International Journal

ENTREPRENEURSHIP AND SUSTAINABILITY ISSUES

ISSN 2345-0282 (online) http://jssidoi.org/jesi/

2018 Volume 5 Number 4 (June)

http://doi.org/10.9770/jesi.2018.5.4(24)

Oakley, A. (1998). Gender, methodology and people's ways of knowing: Some problems with feminism and the paradigm debate in social science. Sociology, 32(4), 707-731. https://doi.org/10.1017/S0038038598000194

OECD. (2010). Open for business: Migrant entrepreneurship in OECD countries. https://doi.org/doi.org/10.1787/9789264095830-en

OECD. (2013). Entrepreneurship at a Glance 2013. http://dx.doi.org/10.1787/entrepreneur_aag-2013-en

Olesen, V. (1994) 'Feminisms and Models of Qualitative Research', in N.K. Denzin and Y.S. Lincoln (eds) Handbook of Qualitative Research. London: Sage

Ogbor, J. O. (2000). Mythicizing and reification in entrepreneurial discourse: Ideology critique of entrepreneurial studies. Journal of Management Studies, 37(5), 605-635. https://doi.org/10.1111/1467-6486.0019

Patton, M. Q. (2015). Qualitative research \& evaluation methods: Integrating theory and practice (4th. ed.). Thousand Oaks, CA: Sage

Peters, M., Frehse, J., \& Buhalis, D. (2009). The importance of lifestyle entrepreneurship: A conceptual study of the tourism industry. Pasos, 7(2), 393-405. Retrieved from http://www.pasosonline.org/Publicados/7309special/PASOS18.pdf\#page=47

Poggesi, S., Mari, M., \& de Vita, L. (2015). What's new in female entrepreneurship research? Answers from the literature. International Entrepreneurship and Management Journal. https://doi.org/10.1007/s11365-015-0364-5

Polit, D. F., \& Beck, C. T. (2014). Essentials of nursing research: appraising evidence for nursing practice (Vol. 8th). Philadelphia: Wolters Kluwer Health/Lippincott Williams \& Wilkins

Ramazanoglu, C. \& Holland, J. (2002). Feminist methodology: Challenge and choices. Thousand Oaks, CA: Sage

Reinharz, S. (1983). Women as Competent Community Builders the Other Side of the Coin. Issues in Mental Health Nursing, 5(1-4), 1943. https://doi.org/10.3109/01612848309009431

Reinharz, S., \& Davidman, L. (1992). Feminist methods in social research. New York: Oxford University Press

Schugurensky, D. (2000). Adult Education and Social Transformation: On Gramsci, Freire, and the Challenge of Comparing Comparisons. Comparative Education Review, 44(4), 515-522. https://doi.org/10.1086/447632

Smith, D. E. (1997). Comment on Hekman's "Truth and Method: Feminist Standpoint Theory Revisited". Signs, 22(2), $392-398$. https://doi.org/10.1086/49516

Wilkinson, S J. and Morton, P (2007). The emerging importance of feminist research paradigms in built environment research, Structural survey, vol. 25, no. 5, pp. 408-417, https://doi.org/10.1108/02630800710838446

Yin, R. K. (2014). Case study research: Design and methods (5th. ed.). Los Angeles, CA: Sage. 
The International Journal

ENTREPRENEURSHIP AND SUSTAINABILITY ISSUES

ISSN 2345-0282 (online) http://jssidoi.org/jesi/

2018 Volume 5 Number 4 (June)

http://doi.org/10.9770/jesi.2018.5.4(24)

Jane NJARAMBA is a PhD candidate at Graduate Research School, James Cook University, North Queensland, Australia. Her research interest is in expanding knowledge of commercial education, management, tourism and services, with a particular focus on researching the experiences of migrant African women entrepreneurs in small businesses.

ORCID ID: orcid.org/0000-0001-6482-8964

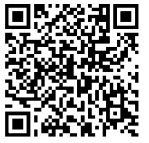

Hilary WHITEHOUSE is an Associate Professor in the College of Arts, Society and Education at James Cook University. She is an environmental and science educator with a strong commitment to researching and teaching climate change education. She is also an expert in qualitative research methodologies in education and has much successful experience as a post-graduate research advisor.

ORCID ID: orcid.org/0000-0001-6751-9753

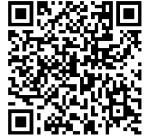

Darren LEE-ROSS is an Associate Professor in the College of Business, Law \& Governance, James Cook University, Australia. His research interests: Hospitality, Tourism seasonality, Entrepreneurship, Decision making theory Of planned behaviour, Entrepreneurs lifestyle, Small business, Job satisfaction, \& Organisational culture.

ORCID ID: orcid.org/0000-0003-3066-7108

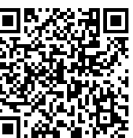

回解踪

Register for an ORCID ID:

https://orcid.org/register

Copyright (C) 2018 by author(s) and VsI Entrepreneurship and Sustainability Center

This work is licensed under the Creative Commons Attribution International License (CC BY).

http://creativecommons.org/licenses/by/4.0/

(c) (†) Open Access 